УДК 613-15; 338; 633.17

\title{
ЭКОНОМИЧЕСКАЯ ЭФФЕКТИВНОСТЬ ТЕХНОЛОГИЧЕСКИХ ПРИЕМОВ ВОЗДЕЛЫВАНИЯ ПРОСА В КБР
}

Хамокова И. аспирант Тутов A.A. Хежева А.А. Альмов А.К. магистранты Догова И.А. студент ФГБОУ ВО Кабардино-Балкарский ГАУ

Аннотация: В работе осуществлены экономические расчеты по схеме: затраты - эффективность. При этом использованы типовые технологические карты по возделыванию проса, которые привязывались к конкретным технологическим приемам полевых опытов. Все цены и затраты по времени показаны на период проведения полевых и производственных опытов: 20192020 гг.

Ключевые слова: просо, экономическая эффективность, рентабельность, сорт, урожайность.

Просо - основная крупяная и кормовая культура в КБР. Площадь ее составляет более 2,5 тыс. га, валовой сбор 0,6-4,6 тыс. тонн при средней урожайности $5,5-18,5$ ц/га. В данное время урожай проса в хозяйствах всех форм собственности низок, что не отвечает значению этой культуры для наших народов КБР.

Экономические расчеты осуществлены по схеме: затраты эффективность. При этом использованы типовые технологические карты по возделыванию проса, которые привязывались к конкретным технологическим приемам полевых опытов. Поэтому нами были уточнены теоретические аспекты повышения экономической эффективности производства проса в КБР.

В расчетах учитывались: стоимость уборки дополнительного урожая по вариантам опытов, стоимость высева дополнительного количества семян 
вследствие увеличения нормы высева, стоимость внесенных минеральных удобрений, включая затраты по их применению. Все цены и затраты по времени показаны на период проведения полевых и производственных опытов: 2019-2020 гг. В зависимости от сроков посева (табл 1.) величина чистого дохода и уровня рентабельности сорта Эльбрус 10 подвергается значительным изменениям.

\section{Таблица 1}

Экономическая эффективность возделывания проса в зависимости от сроков посева (сорт Эльбрус10, 2019-2020 гг.)

\begin{tabular}{|c|l|c|c|c|c|c|c|}
\hline \multirow{2}{*}{$№$} & \multicolumn{1}{|c|}{ Показатели } & \multicolumn{5}{|c|}{ Сроки посева } \\
\cline { 2 - 8 } & 20.04 & 25.04 & 30.04 & 05.05 & 10.05 & 15.05 \\
\hline 1 & Урожай, ц/га & 20,7 & 23,5 & 25,9 & 27,5 & 23,2 & 23,2 \\
\hline 2 & $\begin{array}{l}\text { Цена реализации 1 ц проса, } \\
\text { руб. }\end{array}$ & 734,3 & 734,3 & 734,3 & 734,3 & 734,3 & 734,3 \\
\hline 3 & $\begin{array}{l}\text { Стоимость урожая, тыс. } \\
\text { руб. }\end{array}$ & 15,2 & 17,26 & 19,02 & 20,19 & 17,04 & 17,04 \\
\hline 4 & $\begin{array}{l}\text { Производственные затраты } \\
\text { на 1 га, тыс. руб. }\end{array}$ & 10,51 & 10,62 & 10,72 & 10,79 & 10,61 & 10,61 \\
\hline 5 & Чистый доход, тыс. руб. & 4,69 & 6,24 & 8,3 & 9,4 & 6,43 & 6,43 \\
\hline 6 & Уровень рентабельности, \% & 44,6 & 58,8 & 77,4 & 87,1 & 60,6 & 60,6 \\
\hline
\end{tabular}

Посев 5 мая экономически более выгоден, так как он не требует дополнительных капитальных вложений, кроме как затрат на уборку добавочного урожая. При ранних сроках посева эффективность производства проса заметно ниже. Даже в более поздние сроки уровень рентабельности выше, чем посев до 25 апреля. Однако более эффективным является посев проса в период с 30 апреля по 5 мая, что, очевидно, является наиболее оптимальным временем для получения максимального урожая, наивысшего чистого дохода и уровня рентабельности.

Важное значение при возделывании проса имеет норма высева семян на 1 га площади. Данный агротехнический прием связан с дополнительными затратами средств на посев большого количества семян в весовом отношении, однако он обеспечивает большую прибыль и более высокий уровень рентабельности (табл.2.). 
Таблица 2

Экономическая эффективность возделывания проса сорта Эльбрус 10 в зависимости от нормы высева (среднее за 2019-2020 гг.)

\begin{tabular}{|c|l|c|c|c|}
\hline \multirow{2}{*}{ № } & \multicolumn{2}{|c|}{ Показатели } & \multicolumn{3}{|c|}{ Норма высева, млн. семян на 1 га } \\
\cline { 3 - 5 } & & 3,5 & 4,5 & 5,5 \\
\hline 1 & Урожай, ц/га & 25,4 & 28,6 & 26,5 \\
\hline 2 & Стоимость урожая, тыс. руб. & 18,65 & 21,0 & 19,46 \\
\hline \multirow{2}{*}{3} & Затраты на 1 га, тыс. руб., в т.ч. & & & \\
& на увеличение нормы высева и & 10,70 & 10,87 & 10,92 \\
& уборку дополнительного урожая & - & 1,667 & 1,180 \\
\hline 4 & Чистый доход с 1 га, тыс. руб. & 7,95 & 10,13 & 8,54 \\
\hline 5 & Уровень рентабельности, \% & 74,3 & 93,2 & 78,2 \\
\hline
\end{tabular}

Из данных таблицы 2 видно, что более эффективным агротехническим приемом возделывания проса является посев при норме высева 4,5 млн. семян на 1 га. Уменьшение нормы, также как и увеличение, приводит к снижению экономических показателей эффективности производства проса.

Наиболее эффективным приемом, не требующим дополнительных вложений, можно считать размещение проса по лучшим предшественникам.

Имеются все возможности размешать просо по хорошим предшественникам, так как посевы проса занимают в структуре посевных площадей республики всего 1,5 тыс. гектаров.

Данные таблицы 3 показывают, что лучшим предшественником для проса является горох или озимая пшеница, а худшим - кукуруза на зерно.

Таблица 3

Эффективность возделывания проса по разным предшественникам (среднее за 2019-2020 гг., сорт Эльбрус 10)

\begin{tabular}{|c|l|c|c|c|c|}
\hline \multirow{2}{*}{ № } & \multicolumn{2}{|c|}{ Показатели } & \multicolumn{4}{|c|}{ Предшественники } \\
\cline { 3 - 6 } & Горох & $\begin{array}{c}\text { Озимая } \\
\text { пшеница }\end{array}$ & $\begin{array}{c}\text { Кукуруза на } \\
\text { силос }\end{array}$ & $\begin{array}{c}\text { Кукуруза на } \\
\text { зерно }\end{array}$ \\
\hline 1 & Урожай, ц/га & 34,2 & 31,5 & 28,5 & 25,1 \\
\hline 2 & Стоимость урожая, тыс. руб. & 25,1 & 23,1 & 20,9 & 18,4 \\
\hline 3 & Себестоимость урожая, тыс. руб. & 11,14 & 11,17 & 9,22 & 9,8 \\
\hline 4 & Чистый доход, тыс. руб. & 13,96 & 12,63 & 11,68 & 8,6 \\
\hline 5 & Уровень рентабельности, \% & 125,3 & 120,6 & 126,6 & 87,8 \\
\hline
\end{tabular}


По сравнению с размещением по кукурузе на зерно, по гороху обеспечивается: прибавка урожая на 9,1 ц/га (136,3 \%), чистый доход на 5,36 тыс. руб. (156,5 \%) и уровень рентабельности на $37,5 \%$.

Полученные данные таб. 4 свидетельствуют о том, что под просо экономически выгодно вносить минеральные удобрения, так как дополнительные затраты, связанные с внесением удобрений, окупаются за счет увеличения урожайности и улучшения качества зерна.

Внесение оптимальных доз минеральных удобрений, как показывают наши исследования, повышают эффективность на 36.5 \% (табл.4). Наибольший экономический эффект достигается при внесении на посевах проса полных минеральных удобрений $-\mathrm{N}_{60} \mathrm{P}_{60} \mathrm{~K}_{60}$.

В данном случае окупаемость дополнительных затрат на удобрение повышается более чем на 200 \%.

Таблица 4

\section{Влияние различных доз и видов минеральных удобрений на эффективность производства проса Эльбрус 10}

\begin{tabular}{|c|c|c|c|c|c|c|c|}
\hline \multirow[b]{2}{*}{ № } & \multirow[b]{2}{*}{ Показатели } & \multicolumn{6}{|c|}{ Дозы удобрений } \\
\hline & & $\begin{array}{c}\text { Без } \\
\text { удобрений } \\
\text { (контр.) }\end{array}$ & $\mathrm{P}_{60}$ & $\mathrm{~N}_{60} \mathrm{P}_{60}$ & $\mathrm{~N}_{60} \mathrm{~K}_{60}$ & $\mathrm{P}_{60} \mathrm{~K}_{60}$ & $\mathrm{~N}_{60} \mathrm{P}_{60} \mathrm{~K}_{60}$ \\
\hline 1 & Урожай, ц/га & 20,7 & 23,6 & 28,5 & 26,5 & 28,0 & 30,5 \\
\hline 2 & $\begin{array}{l}\text { Стоимость урожая, тыс. } \\
\text { руб. }\end{array}$ & 15,20 & 17,33 & 20,92 & 19,45 & 20,56 & 22,39 \\
\hline & $\begin{array}{l}\text { Затраты всего, в тыс. } \\
\text { руб., в т.ч.: }\end{array}$ & 10,37 & 10,83 & 11,20 & 11,05 & 10,98 & 11,32 \\
\hline 3 & стоимость удобрений & - & 1,01 & 2,88 & 2,09 & 1,23 & 3,10 \\
\hline & стоимость уборки & - & 1,0 & 0,80 & 1,00 & 0,80 & 0,60 \\
\hline & дополнительного урожая & - & 2,6 & 4,63 & 3,47 & 4,06 & 5,81 \\
\hline 4 & Чистый доход, тыс. руб. & 4,830 & 6,500 & 9,720 & 8,408 & 9,580 & 11,070 \\
\hline 5 & $\begin{array}{l}\text { Уровень рентабельности, } \\
\text { \% }\end{array}$ & 29,7 & 40,0 & 57,0 & 52,92 & 60,3 & 69,7 \\
\hline 6 & $\begin{array}{l}\text { Окупаемость } \\
\text { дополнительных затрат } \\
\text { на удобрение, тыс. руб. }\end{array}$ & - & 4,700 & 6,697 & 6,218 & 7,085 & 10,715 \\
\hline
\end{tabular}

Как видно из представленных таблиц 1-4, возделывание проса в нашей республике является экономически выгодным при соблюдении всех рекомендованных приемов возделывания. 


\section{Список литературы}

1. Малкундуев Х.А., Ханиев М.Х. Возделывание проса в КБР., Нальчик, 1990. ИЗО Эльбрус, 40 с.

2. Сокурова Л.Х. Повышение урожайности и качества зерна проса. Сб. Научных трудов КБНИИСХ, Нальчик, 2002., с. 29-32.

3. Елагин И.Н. Агротехника проса. М. Россельхоз 1981, 158 с. 